\title{
Minor lipid components of some Acacia species: potential dietary health benefits of the unexploited seeds
}

\author{
Nizar Nasri ${ }^{1,4^{*}}$, Walid Elfalleh ${ }^{2}$, Nizar Tlili, ${ }^{1,4}$, Hédia Hannachi ${ }^{3}$, Saida Triki ${ }^{1}$ and Abdelhamid Khaldi ${ }^{4}$
}

\begin{abstract}
Background: Oilseed samples from four Acacia species (A. cyclops, A. ligulata, A. salicina and A. cyanophylla) were analyzed in order to evaluate the potential nutritional value of their unexploited seeds.

Methods: Samples were collected from different Tunisian geographic locations. Seed oils were extracted and carotenoids, tocopherols and sterols were analyzed using chromatographic methods.

Results: The studied Acacia seeds seem to be quite rich in lipids (from 6\% to 12\%). All Acacia species contain mainly the xanthophylls zeaxanthin and lutein compounds: from ca. $38 \mathrm{mg} \cdot \mathrm{kg}^{-1}$ of total lipids (A. cyclops) to ca. $113 \mathrm{mg} . \mathrm{kg}^{-1}$ of total lipids (A. cyanophylla). Total tocopherols varied from ca. $221 \mathrm{mg} . \mathrm{kg}^{-1}$ of total lipids (A. cyclops) to ca. 808 mg. $\mathrm{kg}^{-1}$ of total lipids (A. ligulata). Sterols are highly present and their contents ranged between ca. 7 g. $\mathrm{kg}^{-1}$ of total lipids (A. salicina) and $11 \mathrm{~g} \cdot \mathrm{kg}^{-1}$ of total lipids (A. cyclops).

Conclusion: This study highlights that these unexploited seeds might have a potential nutritional value and encourages researchers to more explore and find developments for these plants for healthy purposes.
\end{abstract}

Keywords: Unexploited Acacia, Oilseeds, Carotenoids, Tocopherols, Sterols

\section{Introduction}

Currently, worldwide interest is oriented for the recovery and exploitation of oils from natural plant resources. Vegetable oils with a high relative amount of minor lipid components are of great importance for human health [1].

Plant sterols (phytosterols) are natural dietary components with serum cholesterol-lowering proprieties. Sterols are a group of fundamental compounds of cell membranes in both plants and animals. The most common plant sterols are $\beta$-sitosterol, campesterol, and stigmasterol, which are classified as 4-desmethylsterols of the cholestane series [2]. The structures of plant sterols are similar to that of cholesterol with an extra methyl or ethyl group and a double bond in the side chain. Unlike cholesterol, they are not synthesized by the human body and are minimally absorbed from the gut [3]. The exact

\footnotetext{
* Correspondence: Nizar.Nasri@fst.rnu.tn

'Laboratoire de Biochimie, Campus Universitaire, Tunis 2092, Tunisia

${ }^{4}$ Institut National de Recherches en Génie Rural Eaux et Forêts, P.B. 10, Ariana 2080, Tunisia

Full list of author information is available at the end of the article
}

mechanism of their cholesterol lowering properties is not fully understood, but plant sterols appear to inhibit the uptake of dietary and biliary cholesterol from the distal small intestine by competing with cholesterol for incorporation into mixed micelles [4]. Plant sterol and stanol-enriched spreads are now widely available commercially as functional foods, but also have specific potential uses in clinical practice. Plant sterols are important ingredients of the blended functional oil [5]. Tocopherols are considered to be the most effective lipid phase natural antioxidants. They prevent lipid peroxidation by acting as peroxyl radical scavengers that terminate chain reactions in membranes and lipoprotein particles. The role of tocopherols in cellular signaling, especially in relation to protein kinase $\mathrm{C}$ was also confirmed [6]. Carotenoids are fat soluble compounds that are associated with the lipidic fractions [7]. Carotenoids are synthesized by plants and many microorganisms. They are recognized mainly as natural antioxidants and enhancers of the immune response [8]. Recently, these properties have increased the interest on the analysis of carotenoids in vegetable samples. 
Nowadays, plant seeds constitute new oil sources, especially from underexploited seeds such as Acacia genus. Little is known about the chemistry of most Acacia species, although the genus is quite large and widespread in the warm sub-arid and arid portions of the world [9]. The Acacia genus comprises approximately 1350 species [10]. The present paper is to investigate, for the first time the carotenoids, tocopherols and sterols from seeds of some Tunisian Acacia species (A. cyclops, A. ligulata, A. salicina and A. cyanophylla). The potential dietary importance of their unexploited seeds is discussed.

\section{Materials and methods Materials}

Samples from fully mature fruits were collected in June 2010 and used in the present study. Acacia seeds were harvested from four species found in Tunisia, respectively A. cyclops, A. ligulata, A. salicina and A. cyanophylla.

\section{Chemicals}

All solvents used during the experiments (methanol, dichloromethane) were purchased from Fluka (Ridel-de Haën, Switzerland). 5 $\alpha$-cholestane, lutein, zeaxanthin, $\alpha$-tocopherol, $\gamma$-tocopherol and $\delta$-tocopherols were purchased from Sigma-Aldrich (Steinheim, Germany). Petroleum ether, potassium hydroxide pellets and anhydrous sodium sulphate were obtained from Merck (Darmstadt, Germany).

\section{Oil extraction}

The oil content was determined according to the reference [11]. About $20 \mathrm{~g}$ of Acacia seeds was ground in a mortar and extracted using petroleum ether in a Soxhlet apparatus for $6 \mathrm{~h}$. The solvent was concentrated using a rotary evaporator under reduced pressure at $45^{\circ} \mathrm{C}$. The oil was dried under a nitrogen stream and stored at $-20^{\circ} \mathrm{C}$ until use. To minimize the decomposition and oxidation of the extracted compounds, all samples were collected in brown glass bottles to prevent UV-activated degradation. All analyses were performed in triplicate.

\section{Extraction of lutein, zeaxanthin and tocopherols}

$40 \mathrm{mg}$ of oil was resuspended in $1 \mathrm{~mL}$ of a mixed HPLC mobile phase: acetonitrile/methanol at $50 \mathrm{mM}$, and ammonium acetate/water/dichloromethane (700:150:50:100, by vol.). After resuspension, the extract was vortexed for 30 s. Samples of $80 \mu \mathrm{L}$ were injected into the HPLC system for the analysis of lutein and zeaxanthin.

\section{HPLC analysis of lutein, zeaxanthin and tocopherols} The HPLC apparatus was a Jasco PU-1580 Plus intelligent pump equipped with an automatic injector system AS300 (Thermo Finnigan, les Ulis, France) and a Jasco MD-1510 plus multi-wavelength detector (JASCO International Co.,
Ltd., Japan). HPLC analyses were carried out using RPHPLC with a Nucleosil C18 column (25 mm x $4.6 \mathrm{~mm}$ id, $5 \mu \mathrm{m}$ particle size) and a VIDAK C18 column (25 mm x $4.6 \mathrm{~mm}$ id, $5 \mu \mathrm{m}$ particle size). The analytical conditions were based on those reported by Lyan et al. [12], with some modifications: Isocratic solvent system; acetonitrile/methanol at $50 \mathrm{mM}$ ammonium acetate/water/ dichloromethane (700:150:50:100, by vol.); flow rate $=2$ $\mathrm{mL} \cdot \mathrm{min}^{-1}$, and detection at $450 \mathrm{~nm}$ for lutein and zeaxanthin and $298 \mathrm{~nm}$ for tocopherols.

\section{Identification of lutein and zeaxanthin}

The identification of lutein, zeaxanthin and tocopherols was ensured by comparing the retention times and absorption spectra of unknown peaks with those of reference standards and by adding lutein, zeaxanthin, $\alpha_{-}, \beta-, \delta-$ tocopherol standards to the sample for co-chromatography.

\section{Preparation of the standard curve}

Six quantities of lutein (range: $0.125-5 \mu \mathrm{g}$ ), zeaxanthin (range: 50-300 ng), $\alpha$-tocopherol (range: 0.5-40 $\mu \mathrm{g}$ ), $\gamma$ tocopherol (range: $1-25 \mu \mathrm{g}$ ) and $\delta$-tocopherol (range: 0.1-2 $\mu \mathrm{g}$ ) were injected into the HPLC system (each standard being dissolved in $1 \mathrm{~mL}$ of the HPLC mobile phase: acetonitrile/methanol at $50 \mathrm{mM}$ ammonium acetate/ water/dichloromethane (700:150:50:100, by vol.). The linear regression equation for each standard curve was then obtained by plotting the amount of the standard compound injected against the peak surface area. The regression equation and correlation coefficient $\left(r^{2}\right)$ were calculated using ChromNav software (JASCO).

\section{Sterol extraction}

A mixture of $50 \mathrm{mg}$ of seed oil, $25 \mu \mathrm{L} 5 \alpha$ cholestane (1 mg.mL ${ }^{-1}$ ) used as an internal standard and $5 \mathrm{~mL}$ methanolic $\mathrm{KOH}(1 \mathrm{~N})$ was saponified in a capped flask for $16 \mathrm{~h}$ at room temperature. $10 \mathrm{~mL}$ distilled water and $10 \mathrm{~mL}$ dichloromethane were then added and mixed. The resulting solution was centrifuged and the lower fraction was kept in a second capped flask. The upper organic layers were washed twice with $10 \mathrm{~mL}$ distilled water, and once with $10 \mathrm{~mL}$ dichloromethane. The resulting solution was centrifuged and the dichloromethane layers were combined and washed twice with $5 \mathrm{~mL}$ and kept in the second capped flask. This solution was filtered and the obtained solvent was evaporated to dryness under nitrogen at $40^{\circ} \mathrm{C}$. After vortexing, the aliquot (matter unsaponifiable with dichloromethane) was derivatized to trimethylsilyl ethers (TMS ether) by the addition of $300 \mu \mathrm{L} \mathrm{N}, \mathrm{O}$-bis(trimethylsilyl)trifluoroacetamide and $50 \mu \mathrm{L}$ pyridine at $60^{\circ} \mathrm{C}$ for $30 \mathrm{~min}$, and then injected into the gas chromatograph. 


\section{Sterol quantification by gas chromatography-flame ionization detection (GC-FID)}

Samples $(2 \mu \mathrm{L})$ were analyzed in duplicate by GC in a Hewlett-Packard HP-4890D chromatograph equipped with a $30 \mathrm{~m}(0.25 \mathrm{~mm}$ i.d., $0.25-\mu \mathrm{m}$ film thickness $)$ DB5 MS fused silica capillary column. The oven temperature was raised from $50^{\circ} \mathrm{C}$ to $290^{\circ} \mathrm{C}$ at a rate of $20^{\circ} \mathrm{C} \mathrm{min}{ }^{-1}$. The flame ionization detector (FID) temperature was $290^{\circ} \mathrm{C}$. The split ratio was 1:20. Helium was used as a carrier gas at a pressure of $120 \mathrm{kPa}$. TMS esters were eluted from the column. The data were processed using EZChrom Elite software (Agilent Technologies, Massy, France). The areas of both sterols were compared to the areas of known quantities of the internal standard (5 $\alpha$-cholestan).

\section{Sterol identification by gas chromatography-mass spectrometry (GC-MS)}

GC-MS analyses of TMS ester derivatives were carried out on a Shimadzu GC 2010 gas chromatograph attached to a Shimatdzu 2010 selective quadrupole mass detector (Shimadzu France, Marne la Vallée) operating in the electronic ionisation mode under an ionisation voltage of $70 \mathrm{eV}$ at $200^{\circ} \mathrm{C}$. Shimadzu software was used for data acquisition and processing. The injector (splitless mode) and the interface temperature were maintained at $290^{\circ} \mathrm{C}$; helium was used as the carrier gas under a constant flow rate of $1 \mathrm{~mL} / \mathrm{min}$. Spectral data were acquired over a mass range of 50-600 amu. GC separation was performed on a DB5 MS fused silica capillary column $(0.25 \mathrm{~mm}$ i.d., $0.25-\mu \mathrm{m}$ film thickness). The temperature was kept at $50^{\circ} \mathrm{C}$ for $1 \mathrm{~min}$, and then raised to $290^{\circ} \mathrm{C}$ for $90 \mathrm{~min}$ at a rate of $20^{\circ} \mathrm{C} \mathrm{min}{ }^{-1}$.

\section{Statistical and chemometric methods}

Data were compared on the basis of standard deviations from mean values. Differences between mean values were based on the one-way analysis of variance with a post-hoc determination using Duncan's multiple range tests performed by Statistica software (version 8). The level of significance was set at $p<0.05$.

\section{Results and discussion Oil content}

Total lipid contents, expressed as percentage on dry weight basis $(\mathrm{dw} \%)$ have a values of $6.83 \mathrm{dw} \%(A . c y c-$ lops), $9.03 \mathrm{dw} \%$ (A. ligulata), $10.05 \mathrm{dw} \%$ (A. cyanophylla) and $12.18 \mathrm{dw} \%$ (A. salicina) (Table 1). The studied Acacia species seem to be quite rich in lipids (from 6 to $12 \%)$ and are well comparable to other species [13-17].

\section{Carotenoid and tocopherol contents}

All Acacia species contain mainly the xanthophylls zeaxanthin and lutein compounds as reported in Table 1. Total amounts of xanthophylls were respectively for $A$. cyclops, A. ligulata, A. salicina and A. cyanophylla: 38.21 mg.kg ${ }^{-1}$ TL (Total Lipids), 50.10 mg. $\mathrm{kg}^{-1}$ TL, $57.04 \mathrm{mg} \cdot \mathrm{kg}^{-1} \mathrm{TL}$, and $113.76 \mathrm{mg} \cdot \mathrm{kg}^{-1} \mathrm{TL}$. Contents of the main compound (lutein) were $35.41 \mathrm{mg} \cdot \mathrm{kg}^{-1} \mathrm{TL}$ (A. cyclops), $43.83 \mathrm{mg} \cdot \mathrm{kg}^{-1} \mathrm{TL}$ (A. ligulata), $54.67 \mathrm{mg} \cdot \mathrm{kg}^{-1} \mathrm{TL}$ (A. salicina) and $109.55 \mathrm{mg} \cdot \mathrm{kg}^{-1} \mathrm{TL}$ (A. cyanophylla). These differences are mainly due to genetic factors. Highly amounts of carotenoids make the genus Acacia a good natural source of these compounds, especially luteins.

As for tocopherols, all Acacia species contain mainly $\alpha$ - and $\gamma$-tocopherols and in some few amounts the $\delta$ tocopherol. Table 1 . The absence of $\beta$-tocopherol was confirmed using the same method previously described. Regarding $\alpha$ and $\gamma$ tocopherol contents for the different studied Acacia, we noticed that $\alpha$-tocopherol is the major compound for A. salicina (404.30 mg. $\mathrm{kg}^{-1} \mathrm{TL}$ ) and A. cyanophylla (560.14 mg.kg $\left.{ }^{-1} \mathrm{TL}\right)$. As for as A. cyclops and A. ligulata, $\gamma$-tocopherols was found to be the major compound, with respectively $127.25 \mathrm{mg} \cdot \mathrm{kg}^{-1}$ TL and 462.14 mg. $\mathrm{kg}^{-1}$ TL. For all Acacia, the total tocopherols ranged between $221.42 \mathrm{mg} \cdot \mathrm{kg}^{-1} \mathrm{TL}$ (Acacia cyclops) and $808.76 \mathrm{mg} \cdot \mathrm{kg}^{-1} \mathrm{TL}$ (Acacia ligulata). Tocopherols from all studied Acacia were highly presented compared to some other vegetable oils like grape seed (142.6 mg. $\left.\mathrm{kg}^{-1} \mathrm{TL}\right)$ and are comparable to those of olive (216.8 mg.kg ${ }^{-1}$ ), flaxseed ( $\left.588.5 \mathrm{mg} . \mathrm{kg}^{-1}\right)$, peanut (398.6 mg. $\left.\mathrm{kg}^{-1}\right)$, pumpkin (508.1 mg.kg ${ }^{-1} \mathrm{TL}$ ), rapeseed (624.6 mg.kg- $\left.{ }^{-1} \mathrm{TL}\right)$, and sunflower (634.4 mg.kg $\left.\mathrm{kg}^{-1} \mathrm{TL}\right)$. But these contents are lower than soybean (1797.6 mg.kg ${ }^{-1}$ $\mathrm{TL})$ or maize (1618.4 mg.kg $\left.{ }^{-1} \mathrm{TL}\right)$, for example [18].

Table 1 Carotenoids and tocopherols ${ }^{\dagger}$ (mg. $\mathrm{kg}^{-1}$ of total lipids) of Acacia seed oils

\begin{tabular}{|c|c|c|c|c|c|c|c|c|}
\hline \multirow[t]{2}{*}{ Species } & \multirow{2}{*}{$\begin{array}{l}\text { Oil content } \\
\text { (dw\%) }\end{array}$} & \multicolumn{3}{|c|}{ Carotenoids } & \multicolumn{3}{|c|}{ Tocopherols } & \multirow{2}{*}{$\begin{array}{l}\text { Total } \\
\text { tocopherols }\end{array}$} \\
\hline & & Lutein & Zeaxanthin & Total carotenoids & a tocopherol & $\gamma$ tocopherol & $\delta$ tocopherol & \\
\hline Acacia ligulata & 9.03 & $43.83^{B C}$ & $6.28^{A}$ & 50.10 & $315.85^{B}$ & $462.14^{\mathrm{A}}$ & $30.77^{\mathrm{A}}$ & 808.76 \\
\hline Acacia cyclops & 6.83 & $35.41^{C}$ & $2.80^{B}$ & 38.21 & $85.51^{C}$ & $127.25^{\mathrm{D}}$ & $8.66^{\mathrm{B}}$ & 221.42 \\
\hline Acacia salicina & 12.18 & $54.67^{\mathrm{B}}$ & $2.37^{\mathrm{B}}$ & 57.04 & $404.30^{B}$ & $155.78^{C}$ & $3.33^{c}$ & 563.41 \\
\hline Acacia cyanophylla & 10.05 & $109.55^{\mathrm{A}}$ & $4.21^{\mathrm{A}}$ & 113.76 & $560.14^{\mathrm{A}}$ & $185.41^{B}$ & $9.15^{B}$ & 754.70 \\
\hline
\end{tabular}

${ }^{\dagger}$ Each value is the mean of duplicate analyses.

Superscript letters with different letters in the same column of species indicate a significant difference $(p<0.05)$ analyzed using Duncan's multiple range test. 
Table 2 Sterols (g. $\mathbf{~ k g}^{-1}$ of total lipids) of Acacia seed oils

\begin{tabular}{|c|c|c|c|c|}
\hline \multirow[t]{2}{*}{ Phytosterols } & \multicolumn{4}{|c|}{ Species } \\
\hline & Acacia ligulata & Acacia cyclops & Acacia salicina & Acacia cyanophylla \\
\hline Cholesterol & $t r^{+t}$ & $0.22^{\mathbf{A}}$ & $0.06^{c}$ & $0.07^{\mathrm{B}}$ \\
\hline${ }^{\Delta 7}$ cholestenol & $\operatorname{tr}$ & $0.03^{A}$ & $0.06^{\mathrm{A}}$ & $\operatorname{tr}$ \\
\hline Campesterol & $0.08^{\mathrm{A}}$ & $0.20^{\mathrm{A}}$ & $0.13^{\mathrm{A}}$ & $0.20^{\mathbf{A}}$ \\
\hline Campestanol & $0.20^{C}$ & $0.42^{\mathbf{A}}$ & $0.11^{\mathrm{D}}$ & $0.27^{\mathbf{B}}$ \\
\hline Stigmasterol & $0.31^{\text {B }}$ & $0.36^{\mathbf{A}}$ & $0.15^{c}$ & $0.29^{\mathbf{B}}$ \\
\hline${ }^{\Delta 7}$ stigmasterol & $0.28^{C}$ & $0.27^{c}$ & $0.57^{\mathbf{A}}$ & $0.36^{\mathbf{B}}$ \\
\hline${ }^{\Delta 7}$ campesterol & $0.35^{\mathrm{C}}$ & $\operatorname{tr}$ & $0.38^{\mathrm{B}}$ & $0.45^{\mathrm{A}}$ \\
\hline$\Delta 5,23$ stigmastadienol & $0.19^{\mathrm{A}}$ & $0.05^{\mathbf{B}}$ & $0.15^{\mathrm{A}, \mathrm{B}}$ & $0.22^{\mathbf{A}}$ \\
\hline$\beta$ sitosterol & $4.15^{\mathrm{B}}$ & $5.40^{\mathrm{A}}$ & $3.48^{c}$ & $4.06^{\mathrm{B}}$ \\
\hline$\Delta 5$ avenasterol & $0.24^{c}$ & $1.13^{\mathrm{A}}$ & $0.38^{\mathbf{B}}$ & $0.33^{\mathrm{B}, \mathrm{C}}$ \\
\hline${ }^{\Delta 7}$ sitosterol & $\operatorname{tr}$ & $\operatorname{tr}$ & $0.21^{\mathbf{A}}$ & $0.20^{\mathbf{A}}$ \\
\hline$\Delta 5,24(25)$ stigmasterol & $0.09^{C}$ & $0.18^{\mathbf{A}}$ & $0.12^{\text {B }}$ & $0.20^{\mathrm{A}}$ \\
\hline$\Delta 5,24$ stigmastadienol & $0.21^{\mathrm{B}}$ & $0.23^{\mathbf{A}}$ & $0.08^{c}$ & $\operatorname{tr}$ \\
\hline${ }^{\Delta 7}$ stigmastenol & $1.11^{\mathrm{C}}$ & $2.57^{\mathbf{A}}$ & $1.22^{\mathrm{C}}$ & $1.78^{\mathbf{B}}$ \\
\hline Cycloartenol & $0.45^{\mathbf{A}}$ & $0.38^{\mathbf{B}}$ & $0.15^{\mathrm{D}}$ & $0.33^{c}$ \\
\hline${ }^{\Delta 7}$ avenasterol & $0.02^{\text {B }}$ & $0.16^{\mathrm{A}}$ & $0.03^{\text {B }}$ & $0.05^{\mathrm{B}}$ \\
\hline 24, methylene cycloartanol & $0.02^{A, B}$ & $\operatorname{tr}$ & $0.05^{\mathrm{A}}$ & $0.06^{\mathrm{A}}$ \\
\hline Citrostadienol & $0.02^{\mathbf{A}}$ & $\operatorname{tr}$ & $\operatorname{tr}$ & $0.05^{\mathbf{A}}$ \\
\hline Total phytosterols & 7.70 & 11.62 & 7.33 & 8.94 \\
\hline
\end{tabular}

${ }^{\dagger}$ Each value is the mean of duplicate analyses.

${ }^{+\dagger}$ tr: traces.

Superscript letters with different letters in the same line of species indicate a significant difference $(p<0.05)$ analyzed using Duncan's multiple range test.

\section{Sterol content}

Sterol contents of the studied Acacia are respectively 7.33 g. $\mathrm{kg}^{-1} \mathrm{TL}$ (A. salicina), $7.70 \mathrm{~g} . \mathrm{kg}^{-1} \mathrm{TL}$ (A. ligulata) $8.94 \mathrm{~g} . \mathrm{kg}^{-1} \mathrm{TL}$ (A. cyanophylla) and $11.62 \mathrm{~g} \cdot \mathrm{kg}^{-1} \mathrm{TL}$ (A. cyclops). All of these contents are higher than soybean (1.61 $\left.\mathrm{g} \mathrm{kg}^{-1}\right)$, almond (1.43 $\left.\mathrm{g} \mathrm{kg}^{-1} \mathrm{TL}\right)$, olive oil (2.21 $\left.\mathrm{g} \mathrm{kg}^{-1} \mathrm{TL}\right)$, or peanut $\left(2.2 \mathrm{~g} \mathrm{~kg}^{-1} \mathrm{TL}\right)$, but still comparable to those of sesame oil (8.65 $\left.\mathrm{mg} \mathrm{kg}^{-1} \mathrm{TL}\right)$ or corn oil (9.68 $\mathrm{mg} \mathrm{kg}^{-1} \mathrm{TL}$ ). New findings are further confirmation of the high nutritional value of the genus Acacia, since sterols are known to decrease the risk of certain types of cancer and enhance immune function [19]. The sterols are also known to reduce serum lowdensity lipoprotein (LDL)-cholesterol level, and food products containing these plant compounds are widely used as a therapeutic dietary option to reduce plasma cholesterol and atherosclerotic risk [20]. For all Acacia species, $\beta$ sitosterol was the major compound (between $45.5 \%$ and $53.9 \%$ ), followed by the $\Delta 7$ stigmastenol (between $14.4 \%$ and $22.1 \%$ ). All other sterols are present with amounts lower than $5.8 \%$ (Table 2). To our knowledge, very few studies were established to evaluate sterols from Acacia species. The phytosterols $\alpha$-spinasterol and stigmast-7-enol have been characterized from A. auriculiformis [21]. Many of these species also contained $5 \alpha$-stigmastanol, $\beta$-sitosterol, and stigmasterol $[9,22]$.

\section{Conclusion}

The studied Acacias seem to be quite rich in lipids (from 6 to $12 \%)$ and are well comparable to other Acacia species. The composition of Acacia species lipid fraction is reported here for the first time. Studied Acacia species contain very high levels of carotenoids, tocopherols and sterols. Carotenoids from studied Acacias reached 113 mg. $\mathrm{kg}^{-1} \mathrm{TL}$ and tocopherols reached 808 mg.kg-1 TL. Sterols reached 11 g. $\mathrm{kg}^{-1}$ TL. As these minor compounds are known to have a wide range of beneficial biological activities and physical properties, the oil from Acacia seeds confirms its nutritional value and dietary importance. This study explores that these unexploited seeds might replace conventional oil types such sunflower or rapeseed oils.

\section{Competing interests}

The authors declare that they have no competing interests.

\section{Authors' contributions}

NN performed experimental work, interpretation and discussion of the results and wrote the paper. WE, NT, HH, ST, KA conceived drafting and revision of the manuscript. All authors read and approved the final manuscript. 


\section{Acknowledgments}

The authors would like to thank the ChemoSens platform (CSGA, INRADijon, France) for its technical support with respect to GC-MS

\section{Author details}

${ }^{1}$ Laboratoire de Biochimie, Campus Universitaire, Tunis 2092, Tunisia. ${ }^{2}$ Institut des Régions Arides, Laboratoire d'Aridoculture et Cultures Oasiennes, Médenine 4119, Tunisia. ${ }^{3}$ Banque Nationale de Gènes, Charguia-1, Tunis 1080, Tunisia. ${ }^{4}$ Institut National de Recherches en Génie Rural Eaux et Forêts, P.B. 10, Ariana 2080, Tunisia.

Received: 12 April 2012 Accepted: 11 May 2012

Published: 11 May 2012

\section{References}

1. Carvalho IS, Miranda I, Pereira H: Evaluation of oil composition of some crops suitable for human nutrition. Ind Crop Prod 2006, 24:75-78.

2. Kochar SP: Influence of processing on sterols of edible vegetable oils. Prog Lipid Res 1983, 22:161-188.

3. Pollak OJ, Kritchevsky D: Monographs in Atherosclerosis. New York: Basel; 1981.

4. Ling $\mathrm{WH}$, Jones PJH: Minireview dietary phytosterols: a review of metabolism, benefits and side effects. Life Sci 1995, 57:195-206.

5. St-Onge MP, Lamarche B, Mauger JF, Jones PJH: Consumption of a functional oil rich in phytosterols and medium-chain triglyceride oil improves plasma lipid profiles in men. J Nutr 2003, 133:1815-1820.

6. Azzi A, Aratri E, Boscoboinik D, Clement S, Ozer NK, Ricciarelli R, Spycher S: Molecular basis of alpha-tocopherol control of smooth muscle cell proliferation. Biofactors 1998, 7:3-14.

7. de Quiros AR-B, Costa HS: Analysis of carotenoids in vegetable and plasma samples: A review. J Food Compos Anal 2006, 19:97-111.

8. van den Berg H, Faulks R, Granado HF, Hirschberg J, Olmedilla B, Sandmann G, Southon S, Stahl W: The potential for the improvement of carotenoid levels in foods and the likely systemic effects. J Sci Food Agr 2000, 80:880-912.

9. Seigler DS: Phytochemistry of Acacia-sensu lato. Biochem Syst Ecol 2003, 31:845-873.

10. Maslin BR, Miller JT, Seigler DS: Overview of the generic status of Acacia (Leguminosae: Mimosoideae). Aust Syst Bot 2003, 16:1-18.

11. ISO, International Organization for Standardization ISO 659:1998: Oil seeds determination of hexane extract (or light petroleum extract), called "oil content". Geneva: ISO; 1999.

12. Lyan B, Azais-Braesco V, Cardinault N, Tyssandier V, Borel P, AlexandreGouabau MC, Grolier P: A simple method for clinical determination of 13 carotenoids in human plasma using an isocratic HPLC method. J Chromatogr B 2001, 751:297-303.

13. Akthar S: Chemical and nutritional evaluation of Genus Acacia of the family Leguminosae of pakistan. Pakistan: Thesis, Institute of Chemistry/University of the Punjab; 1992:240pp.

14. Youzbachi N, Elfalleh W, Tlili N, Gregoire S, Berdeaux O, Salles C, Triki S, Khouja ML, Khaldi A, Nasri N: Unexploited Acacia cyanophylla seeds: potential food sources of $\omega 6$ fatty acids and antioxidants? J Sci Food Agr 2012, 92:1526-1532.

15. Paganuzzi $\vee$, Malerba A: Composition of Acacia salicina Lindl seed oil Comparison with seed oils of other Acacias species. Riv Ital Sostanze Gr 2000, 77:597-607.

16. Glyphis JP, Milton SJ, Siegfried WR: Dispersal of Acacia Cyclops by birds. Oecologia 1981, 48:138-141.

17. Lamarque AL, Fortunato RH, Maestri DM, Guzman CA: Seed components and taxonomy of some species. Biochem Syst Ecol 2000, 28:53-60.

18. Tuberoso CIG, Kowalczyk A, Sarritzu E, Cabras P: Determination of antioxidant compounds and antioxidant activity in commercial oilseeds for food use. Food Chem 2007, 103:1494-1501.

19. Bouic PJ: The role of phytosterols and phytosterolins in immune modulation: a review of the past 10 years. Curr Opin Clin Nutr Metab Care 2001, 4:471-475

20. Calpe-Berdiel L, Escol-Gil JC, Blanco-Vaca F: New insights into the molecular actions of plant sterols and stanols in cholesterol metabolism. Atherosclerosis 2009, 203:18-31.
21. Mahato SB, Pal BC, Price KR: Structure of acaciaside, a triterpenoid trisaccharide from Acacia auriculiformis. Phytochem 1989, 28:207-210

22. Clark-Lewis JW, Dainis I: The phytosterols from Acacia species: a-spinasterol and stigmast-7-enol. Aust J Chem 1967, 20:1961-1974.

doi:10.1186/1476-511X-11-49

Cite this article as: Nasri et al:: Minor lipid components of some Acacia species: potential dietary health benefits of the unexploited seeds. Lipids in Health and Disease 2012 11:49.

\section{Submit your next manuscript to BioMed Central and take full advantage of:}

- Convenient online submission

- Thorough peer review

- No space constraints or color figure charges

- Immediate publication on acceptance

- Inclusion in PubMed, CAS, Scopus and Google Scholar

- Research which is freely available for redistribution 